Borneo Journal of Sciences \& Technology, 3(2): 65-69

DOI: http://doi.org/10.3570/bjost.2021.3.2-11

e-ISSN: 2672-7439

(C) 2018, UCTS Publisher.

$\begin{array}{lll}\text { Submitted: } 25^{\text {th }} \text { December } 2020 & \text { Accepted: } 28^{\text {th }} \text { June } 2021 & \text { Published: } 31^{\text {st }} \text { July } 2021\end{array}$

\title{
Design, Fabrication and Evaluation of continuous Grilling Machine for Pulut Panggang
}

\author{
*Mohd Zahid Abidin, Mohd Shahril Osman, Norhasmillah, Abu Hassan, and Abdul Fattah Ab Razak \\ School of Engineering and Technology, University College of Technology Sarawak (UCTS), \\ 96000 Sibu, Sarawak, Malaysia
}

\begin{abstract}
The development of the continuous grilling machine was based on the traditional grilling technique where pulut panggang were manually exposed to the heat source of burnt charcoal for a period of time until achieved desired characteristics. The traditional grilling technique usually associated with tedious work, time consuming, hot, dusty and smoky environment. A machine aimed for continuous grilling of pulut panggang has been designed, fabricated and evaluated. Several components such as motor, conveyor, heater/burner and exhaust fan were selected and installed. Upon testing, the fabricated unit of grilling machine was able to run continuously and the estimation for production rate were about 600 pieces of grilled pulut panggang per hour at moderate conveyor speed.
\end{abstract}

Keywords: Pulut panggang; continuous grilling; design and fabrication, food machinery.

\section{INTRODUCTION}

Pulut panggang is one of the Sarawak's food heritages and famous snack during breakfast or tea time $[1,2]$. Traditionally, pulut panggang is prepared by wrapping fully cooked glutinous rice in banana leafs and grilled over a hot burning charcoal. A good characteristics of pulut panggang must have a rich taste of coconut milk infused into the glutinous rice. It also must be cooked with perfection just enough to taste the grilled aroma but not to the extent of having a hard, crust and overcooked characteristics. The market demand for pulut panggang is steadily increase against time and population since three decades ago. It was reported that some of the pulut panggang producers produced about 2000 pieces daily during the peak season. Also, one of the famous producer in Sibu district has claimed that their pulut panggang has reached several countries such as Middle East, Vietnam, Brunei and Singapore [3]. Recently, the Malaysian Agriculture Research and Development Institute (MARDI) has successfully developed an innovative packaging materials that suitable to store pulut panggang for a longer period up to 8 months under freezing conditions $[4,5]$.

The industry of pulut panggang seems like promising in the near future. However, based on the current scenario in Sibu district, most of the pulut panggang producers were still applying the traditional grilling technique where the process was tedious and time-consuming. Also, the grilling operators were usually exposed to the hot, smoky and dusty (ashes) environments. In the long run, this unhealthy practise could lead to the lung associated diseases. The grilling is a critical part since this is the step where the uncooked is converted into the cooked pulut panggang. Therefore, this step should be handled carefully to ensure the quality of pulut panggang and the homogeneity are maintained. To the best of the author knowledge, there is no initiative taken by the pulut panggang producers or any parties to enhance the process by developing a suitable machine for continuous grilling.

The design and fabrication of the continuous grilling machine for pulut panggang was based on the design of the Sate Electrical Grilling Machine that has been developed by the Malaysian Agriculture Research Development Institute and Jabatan Tenaga Manusia, Malaysia [6, 7]. The design has a similar operation concept where food is convey through a hot burner as the heat source. The infrared burner installed capable to reach high temperature and produce less smoke as no burning of charcoal as in the traditional technique [7]. Through the traditional grilling technique, the formation of crust and over burnt cases are the common issues due to the inconsistent of the heating exposure. This issues might be minimized if a consistent heat is supplied and the duration of the exposure are controlled throughout the grilling process. Exhaust fan was equipped in this system aimed to reduce the tendency of the operator inhaling the excessive smoke generated through the process.

Corresponding Author: Mohd Zahid Abidin. School of Engineering and Technology, University College of Technology Sarawak (UCTS), zahidabidin@ucts.edu.my 
Design, Fabrication and Evaluation of continuous Grilling Machine for Pulut Panggang

\section{MATERIALS AND METHODS}

\section{Design Considerations and Fabrication}

In designing any food machinery, some considerations should always be given to the critical factors that significantly contribute to the final attributes of the finish product $[2,9,10]$. In this case, a proper considerations were given to the exposure time and temperature to fulfill the functional requirement of the grilling process. As far as these criteria are concerned, the continuous grilling machine has been designed in the range of time and temperature of the conditions developed for the manual grilling process. Besides that, required outcomes and principle of the methods were the following: (i) the mechanism of the continuous grilling machine must be simple but versatile to grill pulut panggang or other foods materials, (ii) capable of being operated by one or two persons, (iii) the construction must be sturdy, strong and movable, (iv) high output of the production rates with consistent grilled characteristics.

A local company has been identified to perform the fabrication based on the submitted design (Figure 1). Fabrication of continuously grilling machine mainly involved three stages: (i) construction of the main body (ii) assemble of the conveyor, (iii) installation of the motor, heater, exhaust fan, control unit and receptacle. Figures 2 and 3 show the front and side views of the fabricated continuous grilling machine.

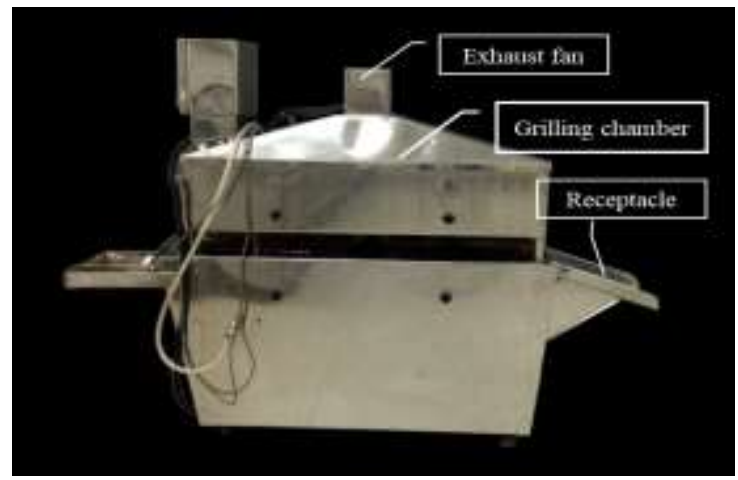

Figure 2: Front view of the continuous grilling machine

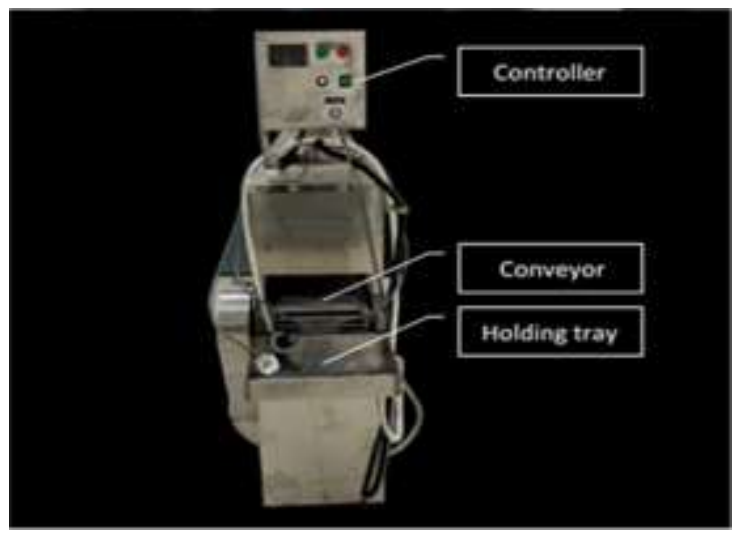

Figure 3: Side view of the continuous grilling machine

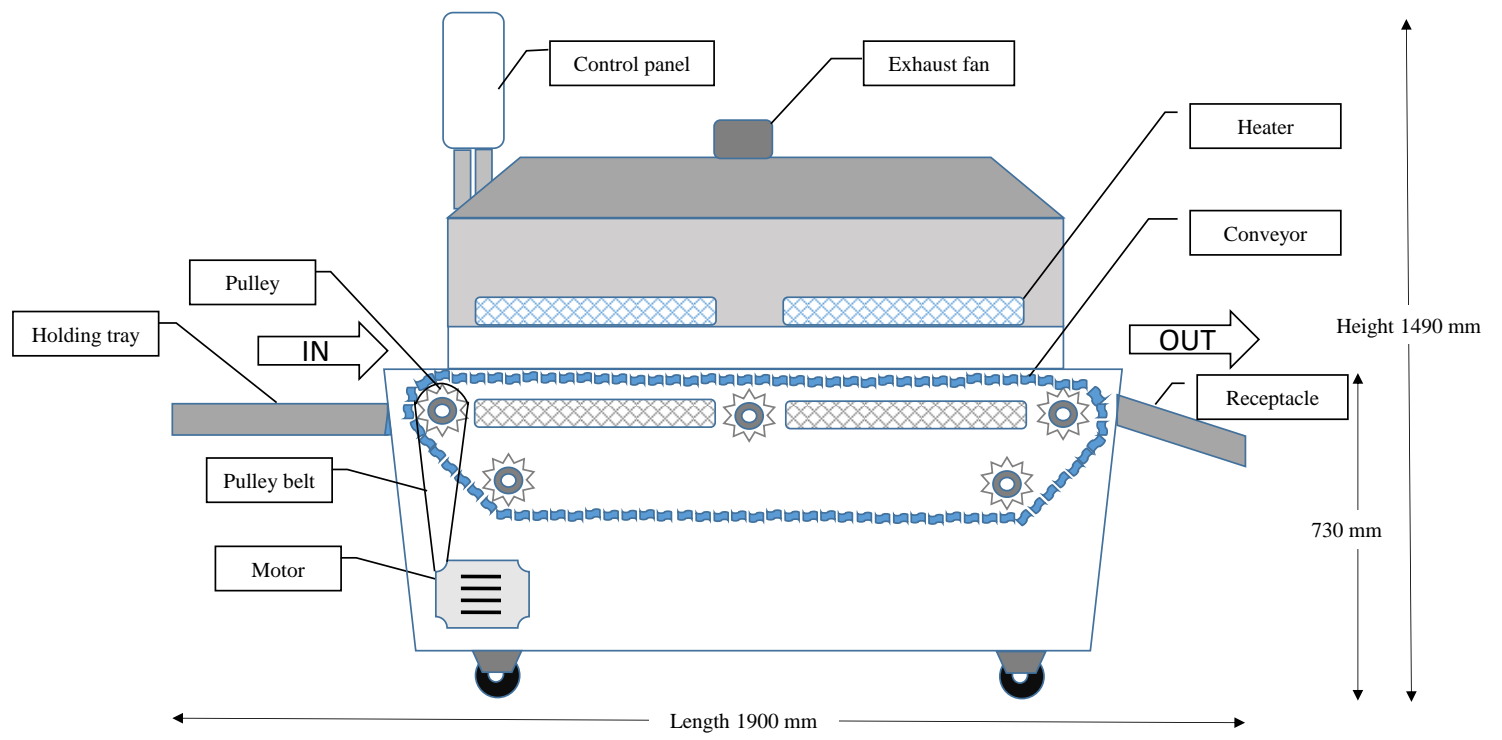

Figure 1: Simple design of the continuous grilling machine. 


\section{RESULTS AND DISCUSSION}

This continuous grilling machine comprised of several major components as listed below:-

$\begin{aligned} \text { i. } & \text { Conveyor } \\ \text { ii. } & \text { Motor } \\ \text { iii. } & \text { Infrared burner } \\ \text { iv. } & \text { Exhaust fan } \\ \text { v. } & \text { Controller } \\ \text { vi. } & \text { Receptacle }\end{aligned}$

Table 1 describes the general specification of the designed and fabricated continuous grilling machine. Most of the materials used to construct the unit were made from the stainless steel type.

Table 1: General specifications of continuous grilling machine

\begin{tabular}{|l|l|}
\hline Criteria & Specification \\
\hline Overall weight & $80 \mathrm{Kg}$ \\
\hline Dimension (L x W x H) & 1900 x 420 x 1490 mm \\
\hline Power & Single phase, 240V \\
\hline Wheels & Heavy duty type \\
\hline Main body materials & Stainless steel type \\
\hline Conveyor & $\begin{array}{l}\text { Chain type (stainless } \\
\text { steel) }\end{array}$ \\
\hline Motor & Simex Motors SM 712-4 \\
\hline Exhaust fan & Snuon DP200A \\
\hline Heater/Burner & Sunsrays infrared burner \\
\hline
\end{tabular}

The dimensions of continuous grilling machine were $1900 \times 420 \times 1490(\mathrm{~L} \times \mathrm{W} \times \mathrm{H})$ expressed in millimeters. This dimension allowed the unit to be operated by minimum of one operator at one time. The operation of the continuous grilling machine start when the uncooked pulut panggang were placed onto the holding tray to ease when handling a high volume of production. The uncooked pulut panggang might also be placed onto the moving conveyor straight away before transferred into a hot grilling chamber under a controlled speed. At the end of the process, a receptacle was installed to receive the hot grilled pulut panggang.

\section{Conveyor}

The conveyor was mainly made from the stainless steel materials which capable to withstand the high temperature during operation. Fig. 5 shows the conveyor for the continuous grilling machine. The width of the conveyor was $250 \mathrm{~mm}$ and overall length was $3010 \mathrm{~mm}$. For each distance of $25 \mathrm{~mm}$ along the conveyor, a stainless steel rod with diameter $7 \mathrm{~mm}$ were installed to hold the pulut panggang. Both ends of the rods were welded to a pair of chains. At one side of the chain was connected to a motor to allow the chain rotate at adjustable motor speed. Another side of the chain was set to be freed.

The installation of the stainless steel rods help to hold the pulut panggang and might also provide an extra support to the chains. The space between the rods allowed the operator to place the pulut panggang firmly.

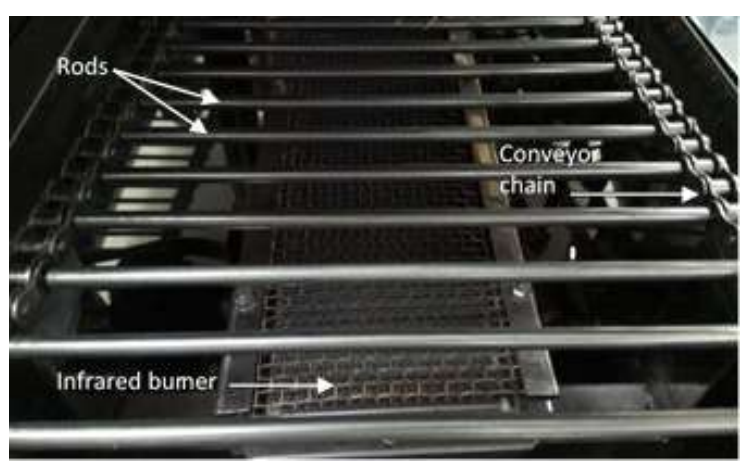

Figure 5: Conveyor and lower heating block for continuous grilling machine

\section{Motor}

A small motor with capacity of $0.37 \mathrm{KW}(0.5 \mathrm{HP})$ was installed to the continuous grilling machine. The function of the motor was to move the conveyor and indirectly controlled the grilling process. Table 2 provides the details information on the motor used

Table 2: Performance Data of Motor (SIMEX Motors, Type SM 712-4)

\begin{tabular}{|l|l|}
\hline Criteria & Values \\
\hline Rated output & $0.37 \mathrm{~kW}$ (or 0.5 HP) \\
\hline Speed at full load & $1330 \mathrm{r} / \mathrm{min}$ \\
\hline $\begin{array}{l}\text { Current at } 415 \mathrm{~V} / 400 \mathrm{~V} / \\
380 \mathrm{~V}\end{array}$ & $1.01 / 110 / 115 \mathrm{amps}$ \\
\hline Torque at full load & $2.6 \mathrm{Nm}$ \\
\hline $\begin{array}{l}\text { Efficiency }(\eta) \text { at } 100 \% / \\
75 \% / 50 \%\end{array}$ & $67.0 \% / 66.5 \% / 62 \%$ \\
\hline $\begin{array}{l}\text { Power factor (cos } \varnothing \text { ) at } \\
100 \% / 75 \% / 50 \%\end{array}$ & $0.75 \% / 0.65 \% / 0.65 \%$ \\
\hline $\begin{array}{l}\text { Direct on line starting in } \\
\text { multiple of full load:- }\end{array}$ & \\
\hline- Torque (LRT) & 2.1 \\
\hline- Current (LRC) & 5.2 \\
\hline - Maximum torque & 2.2 \\
\hline Moment of inertia & $0.0012 \mathrm{~kg} \mathrm{~m}$ \\
\hline Noise level & $57 \mathrm{~dB}(\mathrm{~A})$ \\
\hline Net weight & $15 \mathrm{~kg}$ \\
\hline
\end{tabular}

Infrared Burner 
Four units of infrared burners were installed inside the grilling chamber where two units were placed at the bottom and the others at the upper part to promote homogeneity of the heat supply. Figures 5 show the infrared burner at the bottom of the grilling chamber and Table 4 describe the general info on the infrared burner.

Table 3: General info of the infrared burner

\begin{tabular}{|l|l|}
\hline Criteria & Info/Value \\
\hline Brand/Country origin & Sunsrays/China \\
\hline Model & SGR1602 \\
\hline Dimension $(\mathrm{LxWxH})$ & $554 \times 135 \times 185 \mathrm{~mm}$ \\
\hline Weight & $8 \mathrm{~kg}$ \\
\hline Power source & Natural gas/LPG \\
\hline Gas consumption & $0.46 \mathrm{~kg} / \mathrm{hr}$ \\
\hline Heat output & $5400 \mathrm{Kcal} / \mathrm{hour}$ \\
\hline
\end{tabular}

\section{Exhaust Fan}

One unit of exhaust fan was installed at the top of the grilling chamber aimed to suck out any smoke if produced. Table 5 shows the general info of the exhaust fan used.

Table 4: General info of the exhaust fan

\begin{tabular}{|l|l|}
\hline Criteria & Info/Value \\
\hline Brand/Country origin & Snuon/China \\
\hline Model & DP200A \\
\hline Dimension $(\mathrm{LxWxH})$ & $120 \times 120 \times 38 \mathrm{~mm}$ \\
\hline Fan diameter & $120 \mathrm{~mm}$ \\
\hline Voltage & AC220-240V \\
\hline Rated current & $0.14 \mathrm{~A}$ \\
\hline Speed & $2500 \mathrm{rpm}$ \\
\hline Airflow & $75 \mathrm{CFM}$ \\
\hline Noise & $38 \mathrm{dBA}$ \\
\hline
\end{tabular}

\section{Controller}

Controller for the continuous grilling machine was place at the front and accessible by the operator to control the grilling process. There were several buttons and knobs to control the speed of the conveyor, exhaust fan and also to display the temperature of the grilling chamber. All buttons and knobs were labeled according to the specific functions.

\section{Estimation of the Production Rate}

Production rate or number of pulut panggang can be grilled by the fabricated continuous grilling machine was determined based on the time required for a trial process. The duration was recorded using a digital stopwatch from the initial to the end of the grilling chamber. The measurement was performed at five different speeds from 20 to 30 speed unit according to the scales displayed on the adjustable control knob. The experiment was performed in triplicates and the results were expressed in seconds. Results of the estimation of production rate were tabulated in Table 5 .

Table 5: Time required for completing the grilling process from the start to the end points at different conveyor speeds

\begin{tabular}{|c|c|}
\hline Speeds* $^{*}$ & Duration (s) \\
\hline 20 & $320 \pm 1.25$ \\
\hline 22 & $283 \pm 1.05$ \\
\hline 24 & $269 \pm 1.44$ \\
\hline 26 & $244 \pm 1.27$ \\
\hline 28 & $218 \pm 1.51$ \\
\hline 30 & $215 \pm 1.38$ \\
\hline
\end{tabular}

Note:- The speeds* is based on the scales display at the adjustable control knob.

Based on the data in Table 3, if the continuous grilling machine operates at moderate speed, for instance speed 26, a complete grilling process will take about 244 seconds to produce the first piece of grilled pulut panggang. This number of grilled pulut panggang will increase continuously if the supply of feed materials is constant throughout the one hour period. A trial run at this moderate speed for ten minutes, capable to produce 100 pieces of grilled pulut panggang. This results indicate that high output of grilled pulut panggang can be produced per hour. This number can be considered as high and meet the early consideration to produce high output continuous grilling machine.

\section{CONCLUSION}

A continuous grilling machine has been designed, fabricated and evaluated. Upon testing, the continuous grilling machine was easy to handle by minimum of one operator at one time and capable to run continuously. The estimation of production rate of grilled pulut panggang was 600 pieces per hour at temperature $200^{\circ} \mathrm{C}$ and moderate conveyor's speed.

\section{ACKNOWLEDGMENT}

Thanks are due to University College of Technology Sarawak (UCTS) (Project number: UCTS/RESEARCH/2/2017/05) for technical and financial support.

\section{REFERENCES}


[1] Mohd Nazri A.R., Shahrim A.B., Farah Adibah C.I. and Mohd Mursyid A. 2017. Past and present practices of the Malay food heritage and culture in Malaysia. Journal of Etnic Foods, 4 (4), 221-231.

[2] Berita Harian, Nov 29, 2016.

[3] Borneo Post, July 15, 2013.

[4] Borneo Post, Nov 12, 2016.

[5] Chua H. P., Nicholas D., Suzalyna M., Majelan S., Teresa A.M., Zakaria A.R., Hazijah M.H. and Lorne K. 2019. Processing of frozen Sibu's grilled glutinous rice. Buletin Teknologi MARDI. Bil. 17 (2019):123-128.

[6] Akhbar Utusan Malaysia, Feb 16, 2014.

[7] Harian Metro, Nov 23, 2012.

[8] A. Mohd Zahid, C.S. Cheow, A.R. Norizzah, M.S. Halimahton, M.S. Adi, A.W. Noorakmar, I.
Ruzaina. 2009. Design and Fabrication of Coating-Applicator. Proceeding in International Conference on Applications and Design in Mechanical Engineering (ICADME 2009), 11-13 Oct 2009, Penang. ISBN: 978-967-5415-07-4.

[9] Ashraf A.R., Razak A.Y. and Mohd Zahid, A. 2017. Static Ohmic Heating Design Concept: A Technology, Vol 3, No. 3-4, pp. 33-37. ISSN 2375-9402, USA.

[10] Hafsanjani, S.M., Mohd Zahid, A., Shahril, O., Ashraf, A.R. 2018. Design and fabrication of high pressure reverse osmosis system. In $4^{\text {th }}$ Technology and Innovation International Conference (Techon 2018), 3-5 May 2018, Miri, Sarawak. 